\title{
DETERMINASI DIVERSIFIKASI VERTIKAL PRODUK OLAHAN JAMBU MERAH
}

Determination of Vertical Diversification of Red Guava Products

\author{
Marina Ekawati $^{1)}$, Yuli Wibowo ${ }^{1,2)}$, Kiky Chily Arum Dalu ${ }^{3)}$, Nurhayati $^{1,4) *}$ \\ ${ }^{1)}$ Program Studi Magister Teknologi Agroindustri, Fakultas Teknologi Pertanian, Universitas Jember \\ ${ }^{2}$ Program Studi Teknologi Industri Pertanian, Fakultas Teknologi Pertanian, Universitas Jember \\ ${ }^{3}$ Program Studi Magister Bioteknologi, Pascasarjana, Universitas Jember \\ ${ }^{4)}$ Program Studi Teknologi Hasil Pertanian, Fakultas Teknologi Pertanian, Universitas Jember \\ Jalan Kalimantan No. 37 Kampus Bumi Tegalboto Jember, 68121 \\ *Korespondensi Penulis: nurhayati.ftp@unej.ac.id
}

\begin{abstract}
Red guava as tropical fruit is widely cultivated in Indonesia. The abundant production of red guava is not accompanied by the processing of this fruit with 30-40\% post harvest damage. This study aimed to determine the vertical diversification of red guava products. The study used a descriptive and analytical approach. Vertical diversification of red guava products were juice, puree, jam, "dodol", and crakers. The lowest cost of production was guava juice i.e Rp 5,398.-per unit. Evaluation of sensory showed that guava juice was the most preferred for taste and aroma with score 4.30 (like) and 3.73 (like). The most preferred product for color was "dodol" with score 4.30 (like). Based on production cost and preferred value, guava juice was the most potential as a vertical diversification of guava product than the other products (puree, jam, "dodol", and crakers).
\end{abstract}

Keywords: vertical diversification, jam, juice, production cost, red guava

\section{PENDAHULUAN}

Agroindustri perlu dikembangkan untuk terus mendukung diversifikasi pangan. Diversifikasi pangan adalah usaha untuk menyediakan berbagai ragam produk pangan baik dalam jenis maupun bentuk, sehingga tersedia banyak pilihan bagi konsumen untuk memilih menu makanan yang diinginkan. Konsep diversifikasi pangan meliputi 3 hal, yaitu diversifikasi horizontal (misal mengubah usaha tani yang berbasis padi menjadi usaha tani berbasis tanaman pangan lainnya), diversifikasi vertikal (pengembangan produksi setelah panen) dan diversifikasi regional (penganekaragaman komoditas pangan berdasarkan pendekatan wilayah dan keragaman sosial budaya) (Syah, 2009).

Jambu biji (Psidium guajava L.) merupakan salah satu komoditas buahbuahan dengan jumlah produksi yang tinggi di Indonesia sebesar 200.495 ton pada tahun 2017 (BPS, 2017). Jambu biji merah juga mengandung vitamin $\mathrm{C}$ yang lebih tinggi dibandingkan buah jeruk sebesar $87 \mathrm{mg} / 100 \mathrm{~g}$ (Wirakusumah, 2002). Selain itu, jambu biji merah mengandung $4,99 \%$ serat pangan termasuk polisakarida non pati. Kandungan serat larut dan tidak larut jambu biji merah adalah $1,27 \%$ dan $3,72 \%$ (Thuaytong dan Anprung, 2011). Komoditas ini termasuk buah klimaterik yang mudah rusak, dan memiliki harga jual yang relatif rendah. Parimin (2007) melaporkan bahwa kerusakan pasca panen jambu biji merah mencapai 30-40\%. Angka kerusakan dapat dikurangi dengan adanya diversifikasi olahan jambu biji merah.

Diversifikasi vertikal dari olahan jambu biji merah bias berupa sari buah/jus, puree buah, selai buah, dodol buah, kerupuk buah dan lain sebagainya. Sari buah/jus dihasilkan dari pengepresan buah yang disaring dan bias langsung diminum. 
Jenis minuman sari buah/jus dapat dibagi menjadi dua macam yaitu keruh (cloud juice) dan jernih (clear juice). Sifat keruh padasari buah merupakan parameter fisik yang dikehendaki, terutama berasal dari pektin dan komponen tidak larut yang terdapat pada buah-buahan (Tamaroh, 2004).

Puree buah merupakan hancuran daging buah yang mengandung pulp dengan konsentrasi bubur (Koswara, 2009). Puree (bubur buah) juga diartikan sebagai produk intermediet dalam bentuk lumatan umbi/daging buah yang dipanaskan. Puree dapat dimanfaatkan sebagai bahan dasar pembuatan selai, saus, es krim dan lain sebagainya. Keuntungan dari pengolahan buah menjadi puree adalah menjaga nilai gizi dan cita rasa buah sehingga meningkatkan nilai ekonominya (Ratna et al., 2008). Selai buah merupakan makanan semi padat yang berbahan dasar puree buah dicampur dengan 35-45 bagian gula dan dipanaskan sampai kandungan gulanya berkisar antara 50-65\% (Fachruddin, 2008). Menurut Haryadi (2006) dodol merupakan suatu olahan pangan yang dibuat dari campuran tepung beras ketan, gula kelapa, dan santan kelapa yang didihkan hingga menjadi kental serta berminyak tidak lengket, apabila dingin pasta akan menjadi padat, kenyal dan dapat diiris. Kerupuk merupakan salah satu produk pangan khas Indonesia yang terbuat dari campuran tapioka dan bahan tambahan lain yang digoreng dalam minyak panas sebelum disajikan (Wahyono dan Marzuki, 1996).

Dalam rangka menghasilkan produk komersial dari diversifikasi vertikal pengolahan jambu biji merah dengan mengacu produk optimal pada hasil penelitian sebelumnya yaitu sari buah/jus, puree buah, selai buah, dodol buah dan kerupuk buah, maka dibutuhkan penelitian lanjutan. Tujuan penelitian ini adalah menentukan harga jual pada produk yang berpotensi dari diversifikasi vertikal pengolahan jambu biji merah dan kesukaan panelis dari ragam produk diversifikasi vertikal pengolahan jambu biji merah.

\section{METODE PENELITIAN}

\section{Alat dan Bahan}

Alat yang digunakan dalam penelitian ini yaitu pisau, telenan, timbangan, dandang, kompor (merk Quantum), blender (merk Philip), saringan, pengaduk, thermometer, botol sari buah, cup puree, panci, wajan, botol selai, kuali, baskom, plastik, alumunium foil, tissue roll, sealer, penggaris, benang. Selain itu dibutuhkan alat tulis, kertas, kuesioner, dan komputer.

Bahan utama yang digunakan dalam penelitian ini adalah jambu biji merah yang diperoleh dari Agrotechnopark Universitas Jember Kabupaten Jember dengan varietas getas merah. Bahan tambahan gula pasir (merk lokal), air, pektin, asam sitrat, tepung ketan (merk Rose Brand), santan, tepung tapioka (merk 69), tepung terigu (merk Segitiga Biru), garam (merk Kapal Laut), minyak goreng (merk Bimoli) yang diperoleh dari took bahan kue HMS Jember.

\section{Tahapan Penelitian}

Penelitian ini dilaksanakan dalam tiga tahap penelitian. Tahapannya antara lain pembuatan produk olahan jambu biji merah, menghitung harga pokok produksi (HPP) pada masing-masing produk yang telah dibuat, dan uji sensoris kesukaan dengan parameter yang meliputi rasa, aroma, dan warna.

\section{Pembuatan Sari Buah/Jus Jambu Biji Merah (Hartanti, 2011)}

Pembuatan sari buah/jus jambu biji merah diawali dengan proses pencucian dan pengecilan ukuran jambu. Tahapan selanjutnya adalah homogenisasi antara jambu biji merah dengan air (3:1) menggunakan blender. Penyaringan hasil homogenisasi dilakukan untuk 
memisahkan filtrat dan biji. Proses penambahan $7 \%$ gula pada sari buah dilanjutkan dengan proses pasteurisasi suhu $70^{\circ} \mathrm{C}$ selama 15 menit.

\section{Pembuatan Puree Jambu Biji Merah (Yulistiani et al., 2008)}

Proses pembuatan puree jambu biji merah adalah pencucian buah, pengecilan ukuran, homogenisasi jambu dan air (4:1), penyaringan serta penambahan $0,3 \%$ asam sitrat. Langkah berikutnya adalah pemanasan bubur jambu pada suhu 85$88^{\circ} \mathrm{C}$ selama 15 menit.

\section{Pembuatan Selai Buah Jambu Biji Merah} (Amelia et al., 2016)

Selai jambu biji merah dibuat melalui tahapan pencucian buah, pengecilan ukuran, homogenisasi jambu dan air (7:1), penyaringan, penambahan $0,3 \% \quad(\mathrm{~b} / \mathrm{b})$ asam sitrat serta $1 \%(\mathrm{~b} / \mathrm{b})$ pektin. Campuran dilanjutkan pada proses pemanasan suhu $60-65^{\circ} \mathrm{C}$ selama $3-5$ menit untuk melarutkan pektin dan asam sitrat. Tahap selanjutnya adalah penambahan $60 \% \quad(\mathrm{~b} / \mathrm{b})$ sukrosa, pemanasan suhu $105-110^{\circ} \mathrm{C}$ selama $20-25$ menit dan pengadukan secara kontinu agar selai yang dihasilkan tidak mengkristal.

\section{Pembuatan Dodol Buah Jambu Biji Merah (Lestari et al., 2012)}

Pembuatan dodol jambu biji merah diawali dengan proses pencucian buah, pengecilan ukuran, homogenisasi jambu dan air (4:1), serta penyaringan. Tahapan selanjutnya adalah penambahan $30 \%$ santan kental, $16 \%$ santan cair, $15 \%$ tepung ketan, $35 \%$ gula merah, dan $35 \%$ gula pasir pada bubur buah. Proses pemanasan yang disertai pengadukan dilakukan pada suhu $60-65^{\circ} \mathrm{C}$ selama kurang lebih 3 jam. Pengadukan dilakukan secara kontinu hingga adonan dodol mudah dibalik, tidak lengket dan telah berwarna coklat.

\section{Pembuatan Kerupuk Buah Jambu Biji Merah (Wiyono, 2016)}

Tahapan awal pembuatan kerupuk jambu biji merah adalah pencucian buah, pengecilan ukuran, homogenisasi jambu dan air (4:1), serta penyaringan. Tahapan selanjutnya adalah homogenisasi $65 \mathrm{~g}$ bubur buah dengan $19,5 \mathrm{~g}$ tepung terigu; $110,5 \mathrm{~g}$ tepung tapioka; $6,4 \mathrm{~g}$ gula; $2 \mathrm{~g}$ garam; 5,1 g telur, dan 32,5 mL air. Adonan dilanjutkan dengan proses pencetakan dan pengukusan selama 90 menit. Hasil kukusan adonan dilanjutkan pada proses pendinginan, pengecilan ukuran dan pengeringan dengan cara penjemuran selama \pm 2 hari. Tahapan terakhir adalah penggorengan kerupuk.

\section{Rancangan Percobaan}

Penelitian ini menggunakan metode rancangan acak kelompok (RAK) dengan satu faktor dan lima perlakuan. Faktor tersebut adalah jenis produk olahan jambu, sedangkan perlakuannya adalah sari buah/jus, puree buah, selai buah, dodol buah, dan kerupuk buah. Data dinyatakan dalam bentuk grafik/diagram batang disertai dengan error bar.

\section{Metode Analisis}

Penentuan Harga Pokok Produksi (HPP) (Afif dan Rahmawati, 2017)

Penentuan harga pokok produksi (HPP) adalah penentuan seluruh aspek dari biaya produksi untuk menghasilkan suatu produk dalam rangka memperoleh keuntungan. HPP perlu dilakukan dengan tujuan untuk mengetahui keberhasilan suatu perusahaan. Rumus yang digunakan adalah sebagai berikut:

HPP = Total Biaya Variabel + Total Biaya Tetap (Rp/unit) Volume Produksi

Pengujian Sensoris Produk Diversifikasi Vertikal Jambu Biji Merah

Pengujian sensoris yang digunakan adalah Hedonic Scale Scoring atau yang 
biasa disebut uji kesukaan berdasarkan Setyaningsih et al. (2010) yang telah dimodifikasi. Uji kesukaan dilakukan pada 5 produk olahan jambu yaitu sari buah/jus, puree buah, selai buah, dodol buah, dan kerupuk buah. Produk disajikan pada responden atau panelis tidak terlatih sebanyak 30 orang. Uji sensoris meliputi rasa, aroma, dan warna dimana nantinya masing-masing parameter uji sensoris ini disesuaikan dengan kebutuhan dari 5 produk olahan diversifikasi vertikal jambu biji merah yang telah dibuat. Skala hedonic menggunakan skala likert dengan interval 1-5 yang masing-masing tingkat kesukaan sebagai berikut: 1 (sangat tidak suka); 2 (tidak suka); 3 (netral); 4 (suka); dan 5 (sangat suka).

\section{HASIL DAN PEMBAHASAN}

\section{HPP Produk Olahan Jambu}

Harga pokok produksi (HPP) adalah biaya total, baik biaya variabel ataupun biaya tetap, yang dibutuhkan untuk proses produksi sehingga produk tersebut dapat dijual. HPP digunakan perusahaan untuk memperhitungkan biaya yang dibutuhkan dalam menghasilkan sebuah produksi (Afif dan Rahmawati, 2017). Perhitungan HPP produk olahan jambu direpresentasikan pada industri kecil dengan kapasitas produksi 2.000 unit per hari (Tabel 1).

Tabel 1.Harga pokok produksi (HPP) produk olahan jambu

\begin{tabular}{lcr}
\hline Produk & Netto/kemasan & $\begin{array}{c}\text { HPP } \\
\text { (Rp/unit) }\end{array}$ \\
\hline Kerupuk & $250 \mathrm{gr}$ & 9.780 \\
Selai & $150 \mathrm{gr}$ & 9.925 \\
Puree & $200 \mathrm{gr}$ & 7.928 \\
Dodol & $250 \mathrm{gr}$ & 14.919 \\
Sari buah & $250 \mathrm{~mL}$ & 5.398 \\
\hline
\end{tabular}

Sari buah merupakan produk diversifikasi vertikal olahan jambu yang memiliki nilai HPP terendah yaitu $\mathrm{Rp}$ 5.398,-/unit, sedangkan HPP tertinggi adalah dodol (Rp 14.919,-/unit). Afif dan Rahmawati (2017) menyatakan bahwa salah satu faktor yang mempengaruhi HPP adalah produk hilang dalam proses seperti berkurangnya kadar air pada proses pemanasan. Proses pembuatan sari buah yang lebih sederhana dibandingkan dengan dodol mengakibatkan produk hilang dalam proses pembuatan sari buah lebih sedikit dibandingkan dengan dodol.

\section{Sifat Organoleptik Produk Olahan Jambu \\ Rasa}

Salah satu faktor yang menentukan kesukaan konsumen dalam memilih produk adalah rasa sehingga konsistensi cita rasa suatu produk penting untuk dijaga (Kiay, 2018). Uji organoleptik kesukaan terhadap rasa dilakukan untuk mengetahui kesukaan panelis terhadap rasa produk olahan jambu (Gambar 1).

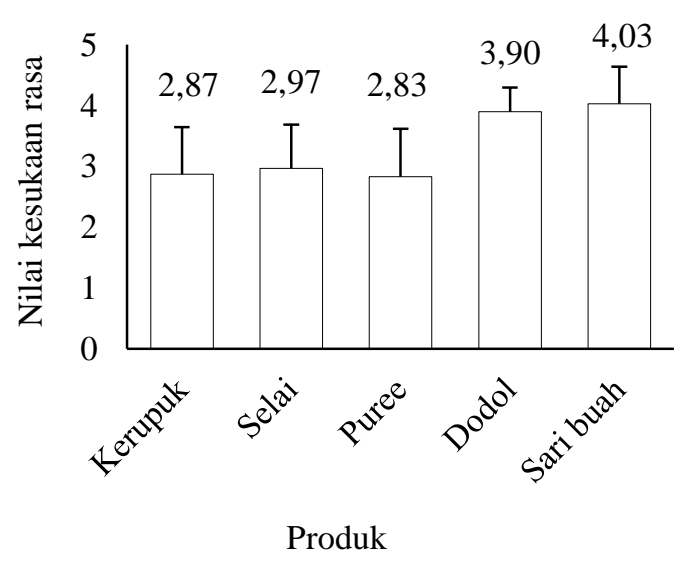

Gambar 1. Nilai kesukaan panelis terhadap rasa produk olahan jambu

Rasa produk olahan jambu yang paling disukai panelis adalah sari buah $(4,03)$, sedangkan produk dengan nilai kesukaan rasa paling rendah adalah puree $(2,83)$. Apabila nilai kesukaan tersebut dibulatkan maka, sari buah dan dodol tergolong disukai panelis, sedangkan kerupuk, selai, serta puree tergolong netral. Faktor yang dapat mempengaruhi penilaian panelis terhadap rasa adalah senyawa kimia, konsentrasi, suhu, dan 
interaksi antar komponen rasa (Kiay, 2018).

Sari buah dan dodol merupakan produk olahan jambu dimana dalam proses pembuatannya dilakukan penambahan sukrosa. Satuhu dan Sunarmani (2004) menyatakan bahwadodolmerupakan salah satu produk olahan hasil pertanian yang termasuk dalam jenis pangan semi basah yang terdiri dari campuran tepung, santan dan gula yang dikeringkan melalui proses pemasakan. Adanya pencampuran cita rasa jambu dan sukrosa dapat meningkatkan nilai kesukaan panelis pada dua produk tersebut.

Puree buah dapat diartikan sebagai hancuran daging buah yang mengandung pulp dengan konsentrasi bubur (Koswara, 2009). Tingginya konsentrasi jambu biji merah dengan penambahan asam sitrat pada puree buah dapat menghasilkan cita rasa perpaduan sepat dan asam. Konsistensi bahan dapat mempengaruhi cita rasa yang ditimbulkan oleh bahan tersebut (Winarno, 2004). Nilamaya (2018) melaporkan bahwa semakin banyak jambu biji merah yang ditambahkan, maka rasanya akan semakin sepat dan asam, dimana rasa sepat diakibatkan oleh kandungan tanin pada jambu. Hal tersebut yang dapat mendasari rendahnya kesukaan panelis terhadap rasa dari puree buah.

\section{Aroma}

Aroma produk pangan turut menjadi salah satu parameter penting yang mempengaruhi nilai kesukaan panelis atau konsumen (Kiay, 2018). Buah jambu biji merah yang telah matang memiliki aroma khas jambu yang wangi dan manis (Nilamaya, 2018). Cahyono (2010) turut menyatakan buah jambu biji memiliki aroma wangi yang khas dikarenakan adanya senyawa eugenol.

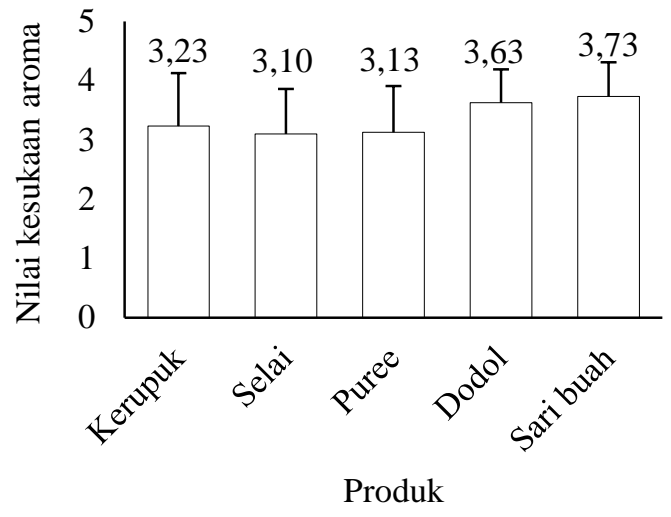

Gambar 2. Nilai kesukaan panelis terhadap aroma produk olahan jambu

Nilai kesukaan panelis terhadap aroma produk olahan jambu yang paling tinggi adalah sari buah $(3,73)$, sedangkan yang terendah adalah selai $(3,10)$ (Gambar 2). Apabila digolongkan, kesukaan panelis terhadap aroma produk olahan jambu sama dengan kesukaan panelis terhadap rasa produk tersebut.

Selai merupakan produk olahan buah dengan tambahan sukrosa dan asam sitrat. Campuran yang dihasilkan dipekatkan sehingga hasil akhirnya mengandung total padatan terlarut minimum $65 \%$ (Fachruddin, 2008). Pemekatan tersebut tentunya membutuhkan pemanasan dengan jangka waktu yang cukup lama. Namun, pemanasan jambu biji merah dapat menimbulkan aroma yang kurang disukai (Ginting et al., 2014). Hal tersebut dapat menjadikan nilai kesukaan panelis terhadap aroma selai paling rendah.

\section{Warna}

Warna adalah salah satu parameter penting dalam penampilan produk pangan yang dapat mempengaruhi selera konsumen (Kiay, 2018). Warna suatu produk dapat bersumber dari warna pigmen alami bahan, penambahan zat warna alami atau sintetik, reaksi karamelisasi, reaksi Maillard, ataupun reaksi senyawa organik dengan udara (Winarno, 1997). Buah jambu biji merah mengandung sekitar 4.100 mikrogram per 100 gram likopen yang merupakan pigmen 
berwarna merah pada buah (Sopandi dan Wardana, 2014).

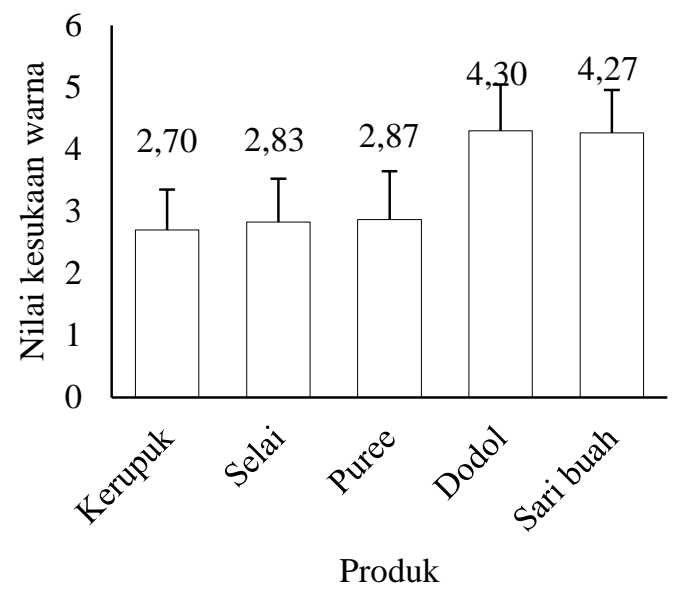

Gambar 3. Nilai kesukaan panelis terhadap warna produk olahan jambu

Pada parameter warna (Gambar 3), nilai kesukaan panelis masih tetap sama dengan dua parameter sebelumnya, dimana dodol dan sari buah tergolong suka dan kerupuk, selai, serta puree tergolong netral. Perbedaannya terletak pada nilai kesukaan warna panelis terhadap dodol $(4,30)$ lebih tinggi dibandingkan sari buah $(4,27)$. Warna produk dengan nilai kesukaan paling rendah adalah kerupuk dengan nilai 2,70. Wahyono dan Marzuki (1996) menyatakan bahwa kerupuk merupakan campuran tapioka dengan bahan tambahan makanan lain dan dilakukan penggorengan menggunakan minyak panas sebelum disajikan.

Rendahnya nilai kesukaan panelis terhadap warna kerupuk dapat dipengaruhi oleh dominannya warna tapioka yang menjadi bahan utama pembuatan kerupuk sehingga warna buah jambu kurang menonjol. Hal ini selaras dengan Widyaningrum (2014) yang melaporkan bahwa warna kerupuk dengan penambahan $75 \%$ puree bit lebih disukai panelis dibandingkan dengan penambahan $25 \%$ dan $50 \%$ puree bit. Hal ini disebabkan oleh warna kerupuk dengan $75 \%$ puree bit lebih berwarna merah keunguan. Wiyono et al. (2015) turut melaporkan bahwa perbandingan jumlah terigu, tapioka, dan bubur jambu biji merah pada kerupuk mempengaruhi nilai kesukaan warna kerupuk, dimana warna kerupuk yang paling disukai adalah kerupuk dengan 50\% bubur jambu biji merah.

Penyebab lainnya dapat dikarenakan adanya proses pencoklatan non enzimatis pada saat proses pemanasan. Kiay (2018) melaporkan bahwa warna suatu produk dapat dipengaruhi oleh teknik memasak ataupun penyimpanan produk. Rosiani et al. (2015) turut melaporkan bahwa kerupuk dengan penambahan daging lidah buaya mengurangi tingkat kesukaan panelis terhadap warna kerupuk akibat penurunan tingkat kecerahan kerupuk setelah proses penggorengan.

Penurunan tingkat kecerahan kerupuk dapat menjadi akibat proses pencoklatan non enzimatis. Rosiani et al. (2015) melaporkan kandungan gizi kerupuk banyak mengandung karbohidrat dan sedikit protein, sehingga gula pereduksi akan bereaksi dengan gugus amina primer dari protein yang menghasilkan pigmen melanoidin yang dapat mengakibatkan warna coklat pada kerupuk. Pada $100 \mathrm{~g}$ jambu biji mengandung 12,2 g karbohidrat dan 0,9 g protein (Wirakusumah, 2002), sehingga dapat memungkinkan terjadinya pencoklatan non enzimatis saat proses pembuatan kerupuk.

\section{KESIMPULAN}

Harga pokok produksi (HPP) terendah dari produk diversifikasi vertikal olahan jambu merah adalah sari buah dengan biaya Rp 5.398,- per unit. Produk olahan jambu yang disukai rasa dan aromanya adalah sari buah dengan nilai rasa 4,03 (disukai) dan nilai aroma 3,73 (disukai). Warna yang disukai adalah produk dodol jambu merah dengan nilai 4,30 (disukai). 


\section{UCAPAN TERIMA KASIH}

Penulis mengucapkan terima kasih kepada Kemenristekdikti atas bantuan dana penelitian melalui skim Penelitian Tesis Magister (PTM) Tahun 2019 dengan Nomor: 061/SP2H/LT/2019.

\section{DAFTAR PUSTAKA}

Afif, M.N., dan Rahmawati, D.R. 2017. Analisis perhitungan harga pokok produksi teh sedap wangi menggunakan metode harga pokok proses pada PT. Sariwangi A.E.A. Jurnal Akunida, 3 (1): $1-19$.

Amelia, Okta, Sussi Astuti, dan Zulferiyenni. 2016. Pengaruh penambahan pektin dan sukrosa terhadap sifat kimia dan sensori selai jambu biji merah (Psidium guava L.). Jurnal Prosiding Seminar Nasional Pengembangan Teknologi Pertanian Politeknik Negeri Lampung. Jurusan Teknologi Hasil Pertanian Fakultas Pertanian Universitas Lampung, Lampung.

BPS. 2018. Statistik Tanaman Buah-buahan dan Sayuran Tahunan Indonesia 2017. Badan Pusat Statistik, Jakarta.

Cahyono, B. 2010. Sukses Budi Daya Jambu Biji di Pekarangan dan Perkebunan. Andi Offset, Yogyakarta.

Fachruddin, L. 2008. Membuat Aneka Selai. Kanisius, Yogyakarta.

Ginting, N.A., Rusmarilin, H., dan Nainggolan, R. 2014. Pengaruh perbandingan jambu biji merah dengan lemon dan konsentrasi gelatin terhadap mutu marshmallow jambu biji merah. Jurnal Rekayasa Pangan dan Pertanian, 2 (3): 16-21.

Hartanti, S. 2011. Pemilihan proses pembuatan sari buah jambu biji (Psidium guava L.) untuk meningkatkan ketahanan waktu saji. Jurnal Widyatama, 20 (2): 123130.

Haryadi. 2006. Teknologi Pengolahan Beras. Gadjah Mada University Press, Yogyakarta.
Kiay, G.S. 2018. Konsentrasi asam sitrat terhadap mutu sari buah mangga Indramayu. Gorontalo Agriculture Technology Journal, 1 (1): 1-8.

Koswara. 2009. Teknologi Pengolahan Sayursayuran dan Buah-buahan (Teori dan Praktek). (EBookpangan.com.) [28 September 2013].

Koswara, S. 2009. Pengolahan Aneka Kerupuk. (EBookpangan.com.) [28 September 2014].

Lestari, N., Isyanti, M., dan Raharjo, S. 2012. Perbaikan teknologi pengolahan dodol jambu biji skala IKM. Warta Industri Hasil Pertanian, 29 (01): 1-11.

Nilamaya, F.A. 2018. "Pengaruh Variasi Konsentrasi Perisa Sari Jambu Biji Merah (Psidium guajava L.) Terhadap Tingkat Kesukaan Panelis dan Kandungan Vitamin C pada Yoghurt Susu UHT (Ultra High Temperature)". Skripsi. Jurusan Pendidikan Matematika dan Ilmu Pengetahuan Alam Fakultas Keguruan dan Ilmu Pendidikan Universitas Sanata Dharma, Yogyakarta.

Parimin, S. P. 2007. Budidaya Jambu Biji Merah. Penebar Swadaya, Jakarta.

Ratna, Y., Rosita dan Lia, K.W. 2008. Pembuatan puree jambu biji merah (kajian konsentrasi asam sitrat dan lama penyimpanan pada suhu kamar). Jurnal Teknologi Pangan, 2 (2): 20-29

Rosiani, N., Basito, Widowati, E. 2015. Kajian karakteristik sensoris fisik dan kimia kerupuk fortifikasi daging lidah buaya (Aloe vera) dengan metode pemanggangan menggunakan microwave. Jurnal Teknologi Hasil Pertanian, 8 (2): 84-98.

Satuhu, S., dan Sunarmani. 2004. Membuat Aneka Dodol Buah. Penebar Swadaya, Jakarta.

Setyaningsih, D., Apriyantoro, A., dan Sari, M.P. 2010. Analisis Sensori Untuk Industri Pangan dan Agro. Cetakan I. IPB. Press, Bogor.

Sopandi dan Wardana. 2014. Mikrobiologi Pangan. CV Andi ofset, Yogyakarta. 
Syah, D. 2009. Riset untuk Mendayagunakan Potensi Lokal: Pelajaran dari Industrialisasi Diversifikasi Pangan. IPB Press, Bogor.

Tamaroh, S. 2004. Usaha peningkatan stabilitas nektar buah jambu biji (Psidium Guajava L) dengan penambahan gum arab dan CMC (Carboxy Methyl Cellulose). Logika, 1 (1).

Thuaytong, W., dan Anprung, P. 2011. Bioactive compounds and prebiotic activity in Thailand-grown red and white guava fruit (Psidium guajava L.). Food Science and Technology International, 17 (3): 205-212.

Wahyono, R., dan Marzuki. 1996. Pembuatan Aneka Kerupuk. Trubus Agrisarana, Surabaya.

Widyaningrum, M.L. 2014. Pengaruh penambahan puree bit (Beta vulgaris) terhadap sifat organoleptik kerupuk. Boga, 3 (1): 233-238.

Winarno, F.G. 2004. Kimia Pangan dan Gizi, Cetakan kesembilan. PT. Gramedia Pustaka Utama,Jakarta.

Winarno, F. G. 1997. Kimia Pangan dan Gizi. Gramedia Pustaka Utama, Jakarta.

Wirakusumah, E. S. 2002. Buah dan Sayur Untuk Terapi. Penebar Swadaya, Jakarta.

Wiyono, A.E., Herlina, Yuwanti, S. 2015. Pengembangan produk kerupuk jambu biji merah (Psidium Guajava L.) skala UMKM. Jurnal Teknologi Pertanian, 16 (2): $137-150$.

Wiyono, A.E. 2016. "Pengembangan Produk Kerupuk Jambu Biji Merah (Psidium guava L.) dan Kelayakan Finansialnya Pada Produksi Skala Mikro". Tesis. Program Studi Magister Teknologi Agroindustri Fakultas Teknologi Pertanian Universitas Jember, Jember.

Yulistiani, R., Rosida, R., dan Lia K. W. 2008. Pembuatan puree jambu biji merah (kajian konsentrasi asam sitrat dan lama penyimpanan pada suhu kamar). Rekapangan: Jurnal Teknologi Pangan, 2 (2): 20-29. 